\title{
Reduction of Heavy Metals Content in Contaminated Vegetables due to the Post-harvest Treatments
}

\author{
Gomaa N. Abdel-Rahman*, Mohamed Bedair M. Ahmed and Diaa A. Marrez \\ Department of Food Toxicology and Contaminants, National Research Centre, 33 \\ El-Bohouth St., Dokki, Giza, Egypt. P.O. Box: 12622, Dokki, Giza, Egypt.
}

\begin{abstract}
$\mathbf{H}$ EAVY metals highly contaminated samples of potato, tomato, and cucumber were used to study the effects of washing, shelling and soaking (in vinegar $5 \%$ for $5 \mathrm{~min}$.) on heavy metals reduction. Heavy metal levels were determined for untreated and treated samples using Atomic Absorption Spectrophotometer and the reduction ratios of heavy metal levels were calculated. The vinegar (acetic acid) effect could be due to its effect on the $\mathrm{pH}$ value that influences the solution chemistry of the heavy metals such as hydrolysis, complexation by organic and inorganic ligands, redox reactions, precipitation and the adsorption availability of the heavy metals. For potato, the results revealed that washing and shelling have removed high ratio of heavy metals, however the reduction was not sufficient to decrease the levels of $\mathrm{Pb}$ and $\mathrm{Cd}$ to be within the MRLs. While soaking in vinegar in addition to washing and shelling of potato has led to a significant decrease in $\mathrm{Pb}$ and $\mathrm{Cd}$ concentrations being lower than the MRLs. For tomato and cucumber, the Cd element was not detected after washing of both vegetable kinds. Lead level in tomato was significantly decreased to the MRLs values when washed and shelled, while $\mathrm{Pb}$ level in cucumber was still higher than MRLs.
\end{abstract}

Keywords: Vegetables, Washing, Soaking, Heavy metals, Household processing.

\section{Introduction}

Vegetables are important food for human health since they have beneficial role in body growth. The main functional constituents of vegetables are protein, carbohydrates, vitamins and minerals. Also, the phytochemicals, such as antioxidant, are found in most vegetables [1]. Although vegetables have several health benefits, but they may contain some chemical hazards especially heavy metals [2].

The main sources for vegetables contamination by heavy metals are contaminated soil, polluted air, pesticides, fertilizers and irrigation by wastewater. Heavy metals can be taken up by vegetables through adsorption from a contaminated soil or by surface deposition from a polluted air [3].

Consumption of vegetables contaminated by heavy metals may cause gastrointestinal cancer [4], pancreas cancer [5], hypertension [6], liver dysfunction [7], lung fibrosis [8], and kidney diseases [9]. As vegetables are mostly consumed after household treatments, so it is necessary to understand the effect of those treatments on the levels of heavy metals. In this respect, Sattar et al.
[10] studied the levels of $\mathrm{Cd}, \mathrm{Hg}, \mathrm{As}, \mathrm{Cr}$ and $\mathrm{Pb}$ in vegetables before and after washing by household chemicals. They found that washing by acetic acid $10 \%$ was more effective for heavy metals removal than tap water, acetic acid 5\%, sodium chloride $5 \%$ and sodium chloride $10 \%$.

Suruchi and Jilani [11] studied the effect of washing by de-ionized water on heavy metals removal from vegetables (spinach, methi and coriander) collected from Agra city, India. The reduction ratios of $\mathrm{Pb}$ were 21, 14 and $11(\%)$ for spinach, methi and coriander, respectively. Meanwhile, reduction ratios of $\mathrm{Cd}$ were 21, 13 and $31(\%)$ for spinach, methi and coriander, respectively.

In addition, Sattar et al. [12] studied the effect of washing by tap water, radish solution (4 or 8 $\%$ ) and ginger solution (4 or $8 \%$ ) on the removal of heavy metals ( $\mathrm{Ar}, \mathrm{Cd}, \mathrm{Cr}$ and $\mathrm{Pb}$ ) in some vegetables (cauliflower, spinach, okra and brinja). They disclosed that washing of vegetables by ginger solution $(8 \%)$ had the highest removal for heavy metals than the other methods. Therefore, the aim of this study was to investigate the effect

*Corresponding author e-mail: gomaa.nrc@gmail.com Tel: 002-0233371433 (2219) - Fax: 002-0233370931

DOI: $10.21608 /$ ejchem.2018.3624.1303

C2017 National Information and Documentation Center (NIDOC) 
of household processing; including washing, shelling, and soaking in vinegar on heavy metal levels in highly contaminated vegetables (potato, tomato and cucumber) of our previous study [2].

\section{Experimental}

Materials and methods

Household processing for vegetables.

Washing by tap water and soaking in vinegar solution (5\%) for $5 \mathrm{~min}$. were applied to the whole fruits of potato, tomato, and cucumber. However, shelling was only applied to potato. Heavy metals concentrations were determined before and after the tested treatments, and ratios of reduction were calculated.

\section{Heavy metals analysis}

Five grams of a vegetable sample were accurately weighed and dried in an oven at $105^{\circ} \mathrm{C}$, then ashed in a muffle furnace at $550^{\circ} \mathrm{C}$. The ash was dissolved using $1 \mathrm{ml} \mathrm{HCl}$ conc. then transferred by de-ionized water to complete the volume of $25 \mathrm{ml}$ [13]. The ash suspension was filtered through an ashless filter paper Whatman No. 42 then determined by Atomic Absorption Spectrophotometer (Agilent Technologies 200
Series AA) at the Central Laboratory, National Research Centre. The determination condition such as preparation of standard solutions, specific wave length for the metals, slit width, detection limits and calculation of metal concentration were applied according to Abdel-Rahman et al. [2].

\section{Statistical analysis}

Results were subjected to one-way analysis of variance (ANOVA) of the general liner model (GLM) using SAS [14] statistical package. The results were the average of three replicates $(\mathrm{p} \leq$ $0.05)$.

\section{$\underline{\text { Results and Discussion }}$}

The levels of $\mathrm{Pb}$ in all untreated vegetables were above the maximum residue limits (MRLs) according to European Commission [15] as shown in Fig. 1. The level of Cd was above MRLs of European Commission [16] only in untreated potato. Meanwhile, concentrations of $\mathrm{Cu}$ and $\mathrm{Ni}$ in all untreated vegetables were below MRLs of Codex [17] and WHO [18], respectively. Chromium was only detected in cucumber and was less than MRLs set by WHO/FAO [19].
$\mathrm{Pb}$

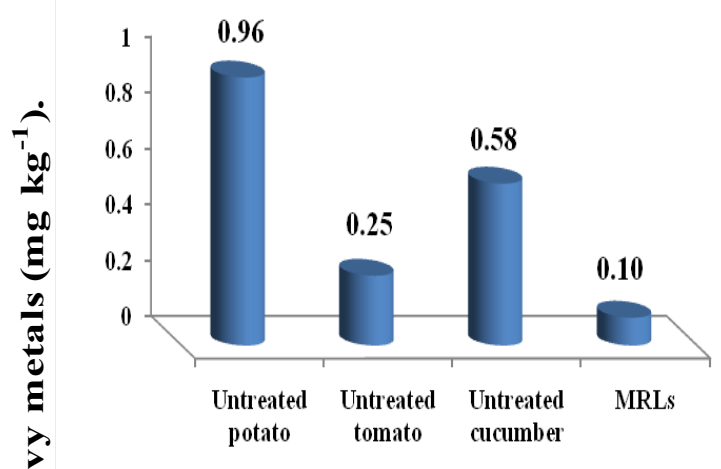

$\mathrm{Cu}$

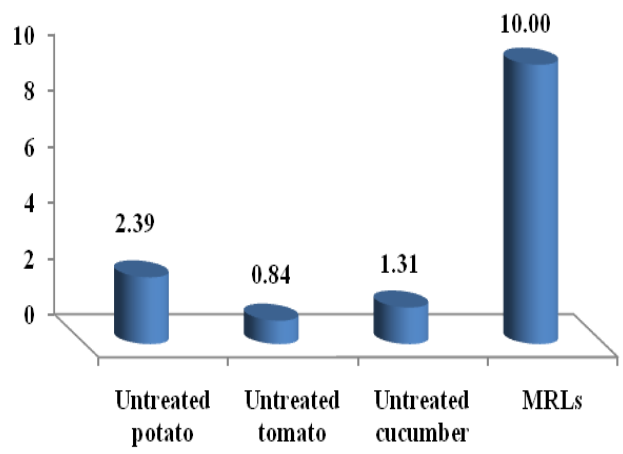

Cd

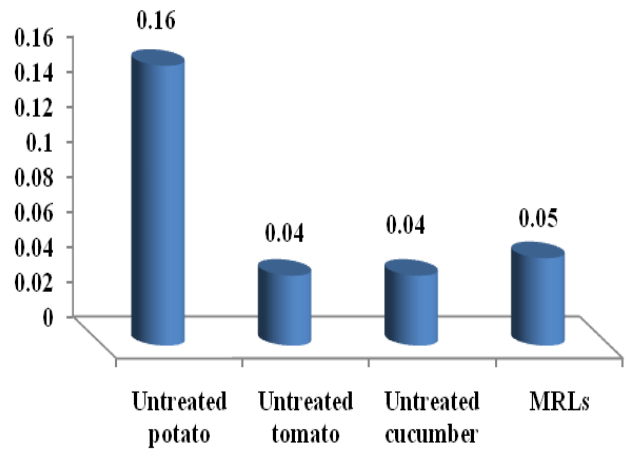

- Ni $\quad \mathrm{Cr}$

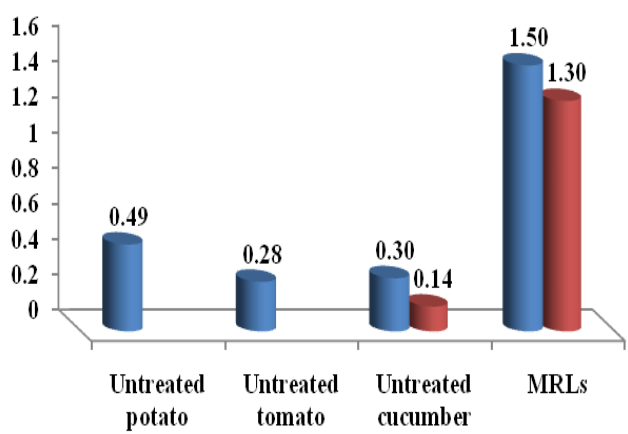

Fig. 1. Concentrations of heavy metals $\left(\mathrm{mg} \mathrm{kg}^{-1}\right)$ in untreated vegetables as compare with MRLs.

Egypt.J.Chem. 61, No.6 (2018) 
The effect of washing, shelling and soaking (in vinegar $5 \%$ for $5 \mathrm{~min}$.) on heavy metals removal in potato samples are summarized in Table 1 . The results revealed that heavy metals of washed potato were decreased by $46,38,31$ and $53(\%)$ for $\mathrm{Pb}, \mathrm{Cd}, \mathrm{Cu}$ and $\mathrm{Ni}$, respectively with significant differences between untreated and washed samples. The washing process was more effective on Ni level in potato.

Shelling of potato following the washing process gave a synergetic effect in the reduction effect on $\mathrm{Pb}, \mathrm{Cd}, \mathrm{Cu}$ and $\mathrm{Ni}$ by $84,63,46$ and $69(\%)$, respectively. So, the shelling process increased the reduction ratios of heavy metals by $38,25,15$ and 16 (\%) for $\mathrm{Pb}, \mathrm{Cd}, \mathrm{Cu}$ and $\mathrm{Ni}$, respectively as compared with washing process. The shelling process was more effective on $\mathrm{Pb}$ level in potato samples which may be return to the $\mathrm{Pb}$ accumulation in potato shells as direct contact with the agriculture soil [20]. The shelling process after washing was not sufficient for the reduction of $\mathrm{Pb}$ and $\mathrm{Cd}$ levels to be lower than MRLs. Significant differences were observed between heavy metals concentrations in shelled and unshelled potato samples except for $\mathrm{Cd}$.
Soaking process (in vinegar for $5 \mathrm{~min}$ ) as third process after washing and shelling increased the reduction ratios of heavy metals from 84 to 92 (\%), from 63 to $81(\%)$, from 46 to $56(\%)$ and from 69 to $84(\%)$ for $\mathrm{Pb}, \mathrm{Cd}, \mathrm{Cu}$ and $\mathrm{Ni}$, respectively. This may be return to acetic acid (vinegar) as a chelating agent for the studied heavy metals [21]. The soaking process was more effective on the reduction ratio of $\mathrm{Cd}(18 \%)$ as compare to shelled and washed potato samples, while, the reduction ratios of $\mathrm{Pb}, \mathrm{Cu}$ and $\mathrm{Ni}$ were 8,10 and $15 \%$, respectively. The levels of $\mathrm{Pb}$ and $\mathrm{Cd}$ of soaked potato samples were below MRLs. No significant differences were observed between heavy metals concentrations before and after soaking except for $\mathrm{Cu}$.

Regarding the effect of household processing on heavy metals residues in tomato, the results were illustrated in Table 2. It was found that the concentrations of $\mathrm{Pb}, \mathrm{Cd}, \mathrm{Cu}$ and Ni were decreased by $60,100,43$ and $57(\%)$, respectively due to the washing process with high significant differences between concentrations of heavy metals in untreated and washed samples. Contamination of tomato samples by $\mathrm{Cd}$ may be attributed to surface

TABLE 1. Effect of household processing on heavy metals levels in potato samples.

\begin{tabular}{|c|c|c|c|c|c|c|c|c|}
\hline \multirow[b]{2}{*}{ Treatment } & \multicolumn{8}{|c|}{ Heavy metals $\left(\mathrm{mgkg}^{-1}\right)$ in potato } \\
\hline & $\mathbf{P b}$ & $\begin{array}{c}\text { Red.* } \\
(\%)\end{array}$ & Cd & $\begin{array}{l}\text { Red. } \\
(\%)\end{array}$ & $\mathrm{Cu}$ & Red. (\%) & $\mathbf{N i}$ & Red. (\%) \\
\hline Untreated & $\begin{array}{c}0.96^{\mathrm{a}} \pm \\
0.03\end{array}$ & 0.0 & $\begin{array}{c}0.16^{\mathrm{a}} \pm \\
0.02\end{array}$ & 0.0 & $\begin{array}{c}2.39^{\mathrm{a}} \pm \\
0.05\end{array}$ & 0.0 & $\begin{array}{c}0.49^{\mathrm{a}} \pm \\
0.03\end{array}$ & 0.0 \\
\hline Washing & $\begin{array}{c}0.52^{\mathrm{b}} \pm \\
0.02\end{array}$ & 46 & $\begin{array}{c}0.10^{\mathrm{b}} \pm \\
0.01\end{array}$ & 38 & $\begin{array}{c}1.64^{\mathrm{b}} \pm \\
0.04\end{array}$ & 31 & $\begin{array}{c}0.23^{\mathrm{b}} \pm \\
0.02\end{array}$ & 53 \\
\hline $\begin{array}{l}\text { Washing } \\
\text { and } \\
\text { shelling }\end{array}$ & $\begin{array}{c}0.15^{\mathrm{c}} \pm \\
0.01\end{array}$ & 84 & $\begin{array}{c}0.06^{\mathrm{bc}} \pm \\
0.01\end{array}$ & 63 & $\begin{array}{c}1.28^{\mathrm{c}} \pm \\
0.03\end{array}$ & 46 & $\begin{array}{c}0.15^{\mathrm{c}} \pm \\
0.01\end{array}$ & 69 \\
\hline $\begin{array}{l}\text { Washing, } \\
\text { shelling } \\
\text { and } \\
\text { soaking }\end{array}$ & $\begin{array}{c}0.08^{\mathrm{c}} \pm \\
0.01\end{array}$ & 92 & $\begin{array}{c}0.03^{\mathrm{c}} \pm \\
0.01\end{array}$ & 81 & $\begin{array}{c}1.06^{\mathrm{d}} \pm \\
0.03\end{array}$ & 56 & $\begin{array}{c}0.08^{\mathrm{c}} \pm \\
0.01\end{array}$ & 84 \\
\hline LSD & 0.08 & & 0.05 & & 0.15 & & 0.08 & \\
\hline
\end{tabular}

*Red.: Reduction

Means followed by different subscripts within column are significantly different at the $5 \%$ level. 
TABLE 2. Effect of household processing on heavy metals levels in tomato samples.

\begin{tabular}{|c|c|c|c|c|c|c|c|c|}
\hline \multirow{2}{*}{ Treatment } & \multicolumn{8}{|c|}{ Heavy metals $\left(\mathrm{mgkg}^{-1}\right)$ in tomato } \\
\hline & $\mathbf{P b}$ & Red.* (\%) & Cd & Red. (\%) & $\mathrm{Cu}$ & Red. (\%) & $\mathbf{N i}$ & Red. (\%) \\
\hline Untreated & $\begin{array}{c}0.25^{\mathrm{a}} \pm \\
0.03\end{array}$ & 0.0 & $\begin{array}{c}0.04^{\mathrm{a}} \pm \\
0.01\end{array}$ & 0.0 & $\begin{array}{c}0.84^{\mathrm{a}} \pm \\
0.04\end{array}$ & 0.0 & $\begin{array}{c}0.28^{\mathrm{a}} \pm \\
0.02\end{array}$ & 0.0 \\
\hline Washing & $\begin{array}{c}0.10^{\mathrm{b}} \pm \\
0.01\end{array}$ & 60 & $<\mathrm{d} .1$ & 100 & $\begin{array}{c}0.48^{\mathrm{b}} \pm \\
0.03\end{array}$ & 43 & $\begin{array}{c}0.12^{\mathrm{b}} \pm \\
0.01\end{array}$ & 57 \\
\hline $\begin{array}{c}\text { Washing } \\
\text { and } \\
\text { soaking }\end{array}$ & $\begin{array}{c}0.04^{\mathrm{b}} \pm \\
0.01\end{array}$ & 84 & $<$ d.1 & 100 & $\begin{array}{c}0.22^{\mathrm{c}} \pm \\
0.02\end{array}$ & 74 & $\begin{array}{c}0.03^{\mathrm{c}} \pm \\
0.01\end{array}$ & 89 \\
\hline LSD & 0.09 & & 0.03 & & 0.14 & & 0.06 & \\
\hline
\end{tabular}

*Red.: Reduction

$<$ d.1.: below the detection limit.

Means followed by different subscripts within column are significantly different at the $5 \%$ level.

deposition from polluted air [3]. So, Cd was not detected in tomato samples after washing process. Meanwhile, $\mathrm{Pb}$ in washed tomato samples was equal to MRLs as $0.1 \mathrm{mg} \mathrm{kg}^{-1}$ [15].

Reduction ratios of heavy metals in tomato samples were increased after soaking (in vinegar for $5 \mathrm{~min}$ ) as 84,74 and $89 \%$ for $\mathrm{Pb}, \mathrm{Cu}$ and $\mathrm{Ni}$, respectively. Soaking, as a second process, had an additional effect on the reduction of $\mathrm{Pb}$, $\mathrm{Cu}$ and $\mathrm{Ni}$ as 24, 31 and $32(\%)$, respectively. Interestingly, the $\mathrm{Pb}$ level of tomato samples after soaking process has been decreased to be lower than MRLs. As well as, significant differences were observed in the concentrations of $\mathrm{Cu}$ and $\mathrm{Ni}$ between the washed and soaked samples of tomato, however no differences for $\mathrm{Pb}$ concentrations were observed between the two processes.

Concerning the cucumber samples, it can be noticed from the result in Table 3 that the levels of $\mathrm{Pb}, \mathrm{Cd}, \mathrm{Cu}, \mathrm{Ni}$ and $\mathrm{Cr}$ in washed samples were decreased by $79,100,63,30$ and $43(\%)$, respectively with significant differences between untreated and washed cucumber. Soaking of washed cucumber in vinegar increased the reduction ratios of $\mathrm{Pb}, \mathrm{Cu}, \mathrm{Ni}$ and $\mathrm{Cr}$ as 81,71 , 53 and $57(\%)$, respectively. So, the additional effects of soaking process on the reduction ratios of $\mathrm{Pb}, \mathrm{Cu}, \mathrm{Ni}$ and $\mathrm{Cr}$ were 3, 8, 23 and 14 (\%), respectively with no significant differences between its levels in washed and soaked cucumber except for $\mathrm{Cu}$. Levels of $\mathrm{Pb}$ in washed and soaked cucumber were slightly over the MRLs, while Cd was not detected after washing process.

Cucumber contains higher levels of biopolymers (such as cellulose, hemicellulose and lignin) than tomato and potato. These biopolymers have many functional groups (carboxyl, hydroxyl, amino, phosphate, and carbonyl) which can act as binding sites for heavy metals [22]. This explains the decrease of total reduction ratios of $\mathrm{Pb}$ and $\mathrm{Ni}$ in cucumber samples as compared with potato and tomato samples. Also, $\mathrm{Cr}$ was only detected in cucumber samples before and after treatments. Meanwhile, $\mathrm{Cr}$ was not detected in untreated potato and tomato samples as previously mentioned in our previous study [2]. On the other hand, total reduction ratio of $\mathrm{Cu}$ in potato samples was lower than in tomato and cucumber samples, and this may be due to the high levels of combined $\mathrm{Cu}$ with potato tissues as naturally [23].

Washing as a practice is easy and effective in most household treatments for vegetables before eating [24]. As the common source of contamination by heavy metals may be attributed to aerial deposition and adhere to vegetables. So, the washing process by water mechanically removes the deposited particles from the vegetable surface [25-27]. Also, Fernandez et al. [28] reported that metals from anthropogenic sources are mainly found in a water soluble form. So, the significant differences between heavy metal concentrations in washed and untreated vegetables suggest that heavy

Egypt.J.Chem. 61, No.6 (2018) 
TABLE 3. Effect of household processing on heavy metals levels in cucumber samples.

\begin{tabular}{|c|c|c|c|c|c|c|c|c|c|c|}
\hline \multirow{2}{*}{ Treatment } & \multicolumn{10}{|c|}{ Heavy metals $\left(\mathrm{mgkg}^{-1}\right)$ in cucumber } \\
\hline & $\mathbf{P b}$ & $\begin{array}{c}\text { Red.* } \\
(\%)\end{array}$ & $\mathrm{Cd}$ & $\begin{array}{l}\text { Red. } \\
(\%)\end{array}$ & $\mathrm{Cu}$ & $\begin{array}{l}\text { Red. } \\
(\%)\end{array}$ & $\mathbf{N i}$ & $\begin{array}{l}\text { Red. } \\
(\%)\end{array}$ & $\mathrm{Cr}$ & $\begin{array}{l}\text { Red. } \\
(\%)\end{array}$ \\
\hline Untreated & $\begin{array}{c}0.58^{\mathrm{a}} \pm \\
0.03\end{array}$ & 0.0 & $\begin{array}{c}0.04^{\mathrm{a}} \pm \\
0.01\end{array}$ & 0.0 & $\begin{array}{c}1.31^{\mathrm{a}} \pm \\
0.02\end{array}$ & 0.0 & $\begin{array}{c}0.30^{\mathrm{a}} \pm \\
0.03\end{array}$ & 0.0 & $\begin{array}{c}0.14^{\mathrm{a}} \pm \\
0.01\end{array}$ & 0.0 \\
\hline Washing & $\begin{array}{c}0.12^{b} \pm \\
0.01\end{array}$ & 79 & $<\mathrm{d} .1$ & 100 & $\begin{array}{c}0.48^{b} \pm \\
0.02\end{array}$ & 63 & $\begin{array}{c}0.21^{\mathrm{b}} \pm \\
0.01\end{array}$ & 30 & $\begin{array}{c}0.08^{\mathrm{b}} \pm \\
0.01\end{array}$ & 43 \\
\hline $\begin{array}{l}\text { Washing } \\
\text { and } \\
\text { soaking }\end{array}$ & $\begin{array}{c}0.11^{\mathrm{b}} \pm \\
0.01\end{array}$ & 81 & $<\mathrm{d} .1$ & 100 & $\begin{array}{c}0.38^{\mathrm{c}} \pm \\
0.01\end{array}$ & 71 & $\begin{array}{c}0.14^{\mathrm{b}} \pm \\
0.01\end{array}$ & 53 & $\begin{array}{c}0.06^{\mathrm{b}} \pm \\
0.01\end{array}$ & 57 \\
\hline LSD & 0.09 & & 0.03 & & 0.08 & & 0.09 & & 0.05 & \\
\hline
\end{tabular}

*Red.: Reduction $\quad<$ d.l. : below the detection limit.

Means followed by different subscripts within column are significantly different at the $5 \%$ level.

metals can reach the studied vegetables by aerial deposition and dissolve in water. These results are in agreement with those obtained by Sing [29] who reported that, about $75-100 \%$ of $\mathrm{Pb}$ and $\mathrm{Cd}$ and $27-55 \%$ of $\mathrm{Cu}$ were reduced, when the vegetable samples were washed by a clean tap water.

Also, the reduction of heavy metals in vegetables by vinegar (acetic acid) could be due to the change of $\mathrm{pH}$ value. The $\mathrm{pH}$ value of a solution influences the solution chemistry of the heavy metals such as hydrolysis, complexation by organic and inorganic ligands, redox reactions, precipitation, the speciation and the adsorption availability of the heavy metals [30].

\section{Conclusion}

The levels of $\mathrm{Cu}, \mathrm{Ni}$ and $\mathrm{Cr}$ in untreated vegetables were below the maximum residue limits (MRLs). Meanwhile, the Pb levels in all untreated vegetables were above the MRLs and the level of Cd was higher than the MRLs only in untreated potato. The highest ratios of heavy metals reduction in vegetables were achieved by the washing process. The heavy metals in potato were decreased by 46, 38, 31 and $53(\%)$ for $\mathrm{Pb}$, $\mathrm{Cd}, \mathrm{Cu}$ and $\mathrm{Ni}$, respectively and by $60,100,43$ and $57(\%)$ as the same order in tomato. Also, the ratios of heavy metals reduction in cucumber after washing process were 79, 100, 63, 30 and 43 (\%) for $\mathrm{Pb}, \mathrm{Cd}, \mathrm{Cu}, \mathrm{Ni}$ and $\mathrm{Cr}$, respectively. The potato shelling as a second process after washing was not satisfied to decrease the levels of $\mathrm{Pb}$ and Cd to MRLs, but their levels were below MRLs after soaking as the third process. Level of $\mathrm{Pb}$ in tomato was equal to MRLs after washing and was below MRLs after soaking. Meanwhile, level of $\mathrm{Pb}$ in cucumber was slightly over the MRLs after washing and soaking processes. Finally, levels of $\mathrm{Cd}$ in tomato and cucumber were not detected after the washing process.

\section{Acknowledgments}

The present study was derived from the research project No. 11040303 (2016 - 2019) which was financially supported by the National Research Centre; Instrumental analyses were supported by Food Toxins and Contaminants Dept., and the Central Laboratory of the National Research Centre, Cairo, Egypt.

\section{References}

1. Wargovich, M.J., Anticancer properties of fruits and vegetables. Journal of Horticultural Science, 35, 573-575 (2000).

2. Abdel-Rahman G.N., Ahmed M.B.M., Saleh E.M. and Fouzy A.S.M., Estimated heavy metal residues in Egyptian vegetables in comparison with previous studies and the recommended tolerable limits. J. Biol. Sci., 18 (3), 135-143 (2018).

Egypt.J.Chem. 61, No.6 (2018) 
3. Zurera G., Moreno R., Salmeron J. and Pozo R., Heavy metal uptake from greenhouse border soils for edible vegetables. Journal of the Science of Food and Agriculture, 49, 307-314 (1989).

4. Steenland K. and Boffetta P., Lead and cancer in humans: where are we now? Am. J. Ind. Med., 38, 295-299 (2000).

5. Jarup L., Hazards of heavy metal contamination. Br. Med. Bull., 68, 167-182 (2003)

6. Lokeshappa B., Shivpuri K., Tripathi V. and Dikshit A.K., Assessment of toxic metals in agricultural produce. Food Publ. Health, 2, 24-29 (2012).

7. Herojeet R., Rishi M.S. and Kishore N., Integrated approach of heavy metal pollution indices and complexity quantification using chemometric models in the Sirsa Basin, Nalagarh valley, Himachal Pradesh, India. Chin. J. Geochem., 34 (4), 620-633 (2015).

8. Kim H.S., Kim Y.J. and Seo Y.R., An overview of carcinogenic heavy metal: molecular toxicity mechanism and prevention. J. Cancer Prev., 20 (4), 232-240 (2015)

9. Singh U.K. and Kumar B., Pathways of heavy metals contamination and associated human health risk in Ajay River basin, India. Chemosphere, 174, 183-199 (2017).

10. Sattar M.U., Khan M.A., Khalil A.A. and Amir R.M., Mitigation of heavy metals in vegetables through washing with house hold chemicals. International Journal of Agricultural Science and Research, 3 (5), 1-12 (2013).

11. Suruchi K. and Jilani A., Assessment of heavy metal concentration in washed and unwashed vegetables exposed to different degrees of pollution in Agra, India. Electronic Journal of Environmental, Agricultural and Food Chemistry, 10 (8), 2700-2710 (2011)

12. Sattar M.U., Anjum F.M. and Sameen A., Mitigation of heavy metals in different vegetables through biological washing techniques. International Journal of Food and Allied Sciences, 1(2), 40-44 (2015).

13. AOAC, Official methods of analysis. Beverages: Malt Beverages and Brewing Materials, 17th ed., Washington, D. C., pp. 74-103 (2000).

Egypt.J.Chem. 61, No.6 (2018)
14. SAS, Statistical Analysis System, SAS / STAT User's Guide. Release 6.03 Edn. SAS Institute, Cary, NC, 1028 PP. (1999).

15. European Commission, Commission Regulation (EU) $2015 / 1005$ of 25 June 2015 amending Regulation (EC) No $1881 / 2006$ as regards maximum levels of lead in certain foodstuffs. Official Journal of the European Communities, 161, 9-13 (2015).

16. European Commission, Commission Regulation (EU) 488/2014 of 12 May 2014 amending Regulation (EC) No $1881 / 2006$ as regards maximum levels of cadmium in foodstuffs. Official Journal of the European Communities, 138, 75-79 (2014).

17. Codex, Codex Alimentarius Commission, Joint FAO/WHO. General Standard for Contaminants and Toxins in Foods (1998).

18. WHO, Joint FAO/WHO Expert standards program codex Alimentation Commission. Geneva, Switzerland. Available online http://www.who. int. Accessed 10 March 2018 (2007).

19. WHO / FAO, Expert committee on food additives. Cambridge: Cambridge University Press, 329-336 (2007).

20. Khan Z.I., Ahmad K., Yasmeen S., Akram N.A., Ashraf M. and Mehmood N., Potential health risk assessment of potato (Solanum tuberosum L.) grown on metal contaminated soils in the central zone of Punjab, Pakistan. Chemosphere, 166, $157-$ 162 (2017).

21. Supraptia N.H., Bambangb A.N., Swastawatic F. and Kurniasih R.A., Removal of heavy metals from a contaminated green mussel [Perna viridis (Linneaus, 1758)] using acetic acid as chelating agents. Aquatic Procedia, 7, 154-159 (2016).

22. Basu M., Guha A.K. and Ray L., Adsorption of lead on cucumber peel. Journal of Cleaner Production, 151, 603-615 (2017).

23. Radwan M.A. and Salama A.K., Market basket survey for some heavy metals in Egyptian fruits and vegetables. Food Chem. Toxicol., 44, $1273-$ 1278 (2006).

24. Krol W.J., Arsenault T.L., Pylypiw H.J. and Incorvia M.J., Reduction of pesticide residues on produce by rinsing. Journal of Agriculture and Food Chemistry, 48, 4666-4670 (2000). 
25. Dasch J.M., Measurement of dry deposition to surfaces in deciduous pine. Environ. Pollut., 44, 261-277 (1987).

26. De Nicola, Maisto F.G., Prati M.V. and Alfani A., Leaf accumulation of trace metals and polycyclic aromatic hydrocarbons (PAHS) in Quercus ilex L. Environ. Pollut., 154, 254-263 (2008).

27. Sharma R.K., Agarwal M. and Marshall F.M., Heavy metal contamination in vegetables in urban India-a case study in Varanasi. Environ. Pollu., 154, 254-263 (2008).

28. Fernandez E., Ternerio R.A.J.M., Baragan F.J., De La Rosa and Sanchez J.C.A., Chemical speciation of trace metals for fineurban particles. Atmos. Emviron., 36, 773-780 (2002).

29. Singh M., An evaluation of heavy metals concentration in vegetables grown in the vicinity of industrial area. Journal of Agroalimentary Processes and Technology, 17(1), 36-41 (2004).

30. Esposito A., Pagnanelli F. and Veglio F., pHrelated equilibria models for biosorption in single metal systems. Chem. Eng. Sci., 57, 307-313 (2002).

(Received 24/4/2018; accepted 29/7/2018)

\section{خفض محتوى العناصر المعدنية الثقيلة فى الخضروات الملوثئة خلال معاملات ما بعد الحصاد}

جمعه نور الاين عبد الرحمن، محمد بدير محمد أحمد و ضياء عطية مريز

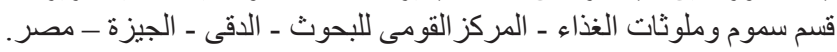

\footnotetext{
فى الدر اسة الحالية تم إستخدام عينات من البطاطس و الطماطم و الخيار ذات مستوى عال من التلوث الثات بالعناصر

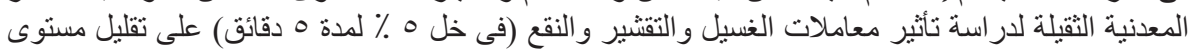

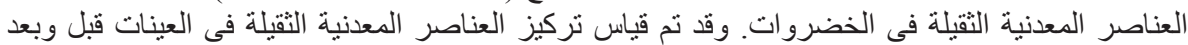

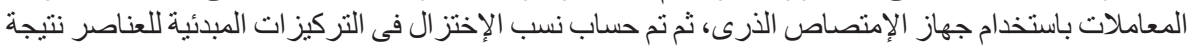

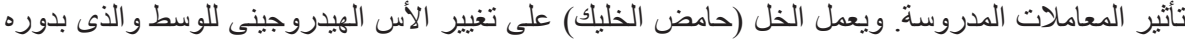

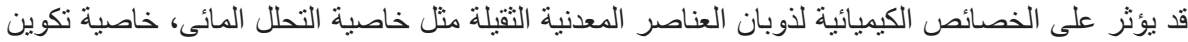

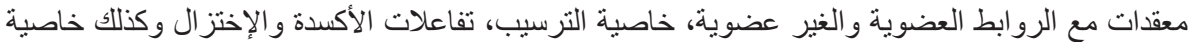

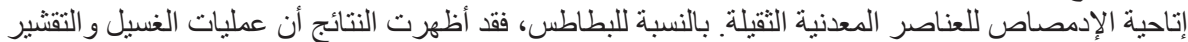

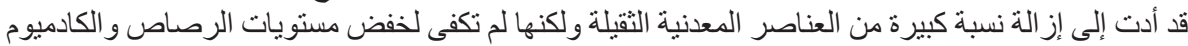

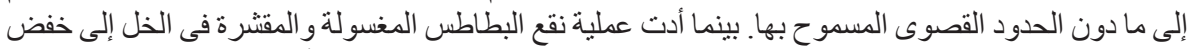

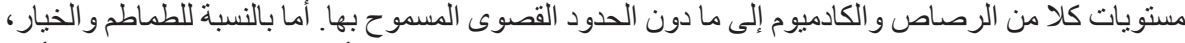

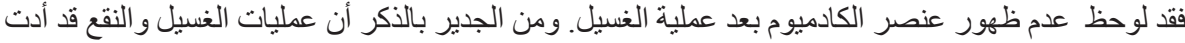

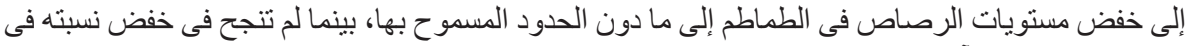

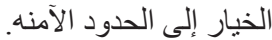

